\title{
Konlk REPRESENTASI BUNGA DALAM FOTOGRAFI EKSPRESI
}

Volume 1, Nomor 1

Juli 2019,

(29-36)

\section{Galuh Paramithasari}

Institut Seni Indonesia Yogyakarta

e-mail : gparamithasari@gmail.com

\begin{abstract}
ABSTRAK
Memotret tanpa menggunakan kamera bukan lagi sesuatu yang mustahil. Adanya alternatif lain untuk menciptakan sebuah karya seni tanpa menggunakan kamera merupakan sebuah transformasi dari ide lama. Sebelum fotografi berkembang, di zaman fotografi analog memotret tanpa menggunakan kamera disebut dengan fotogram. Namun, di zaman fotografi digital memotret tanpa menggunakan kamera bisa saja diciptakan dengan menggunakan alat bernama scanner. Penciptaan karya fotografi ini sering disebut juga dengan scanography singkatan dari scanner photography atau dikenal juga dengan scanner-art. Kedua teknik ini menghasilkan sebuah karya seni tanpa menggunakan kamera, namun prinsip kerja fotografinya tetap menggunakan cahaya. Dalam penciptaan tugas akhir ini, scanography diperkenalkan sebagai media berekspresi yang baru dalam dunia fotografi. Visual yang dihasilkan dari teknik scanography memperlihatkan detail objek seperti fotografi makro sebagai wujud kedekatan antara objek dengan perasaan-perasaan yang bergejolak untuk disampaikan melalui sebuah karya. Perasaan-perasaan seperti ketakutan, kebahagiaan, kesedihan, impian kemudian direpresentasikan oleh bunga. Objek bunga digunakan sebagai wujud identitas diri seniman sebagai seorang perempuan dan perasaan-perasaan yang dialami dalam kehidupannya. Pemanfaatan objek di sekitar sebagai permainan tanda dan simbol yang dirasa tidak asing untuk digabungkan kedalam sebuah karya memperkuat makna dan perasaan yang sedang dialaminya. Eksplorasi-eksplorasi yang dihasilkan juga tidak lepas dari permainan teknik fotografi dan komposisi fotografi untuk membentuk sebuah visual yang menarik.
\end{abstract}

Kata kunci : scanography, scanner, fotografi ekspresi, bunga, perasaan, representasi.

\begin{abstract}
Take a picture without using a camera is no longer an impossible thing. The existence of other alternatives to creating a work of art without using a camera is a transformation from an old idea. Before photography developed, in the era of analog photography taking picture without using a camera was called a photogram. However, in the digital photography era could have been created using a tool called a scanner. The creation of this photographic work is often referred to as scanography stands for scanners photography, also known as scanner-art. Both of these techniques produce a work of art without using a camera, but the working principle of the photography still uses light. In the creation of final project, scanography was introduced as a new expression media in the world of photography. The visuals produced from the scanography technique show details of objects such as macro photography as a manifestation of the closeness between objects and feelings to be conveyed through a work. Feelings like fear, happiness, sadness, dreams are represented by flowers. The object of interest is used as a manifestation of the artist's identity as a woman and the feelings experienced in her life. Using objects around as a signs and symbols that are familiar to be combined into a work strengthens the meaning and feeling that is being experienced. The explorations are also inseparable from the photography techniques and the composition of photography to form an interesting visual.
\end{abstract}

Keywords: scanography, scanner, photography expression, interest, feeling, representation.

\section{PENDAHULUAN}

Lahirnya sebuah karya seni merupakan sebuah ungkapan perasaan, keindahan, emosi, pengalaman-pengalaman dan sebagainya dari seorang seniman dengan medianya. Menurut Soedjono (2007:27), penciptaan karya seni fotografi bisa didasarkan untuk berbagai kepentingan dengan menyebutnya sebagai suatu medium 'penyampaian pesan' (message carrier) bagi tujuan tertentu. Karya fotografi di samping kediriannya yang mandiri juga dimanfaatkan bagi memenuhi suatu fungsi tertentu. Sebuah karya fotografi yang dirancang dengan konsep tertentu dengan memilih objek foto yang terpilih dan yang diproses dan dihadirkan bagi kepentingan si pemotretnya sebagai bahan luahan ekspresi artistik dirinya. Dalam hal ini karya fotografi tersebut dimaknakan 
sebagai suatu medium ekspresi yang menampilkan jati diri si pemotretnya dalam proses berkesenian penciptaan karya fotografi seni.

Seni fotografi merupakan perpaduan antara teknologi dan seni. Berbagai nilai estetika yang tidak tercakup dalam teknologi fotografi harus diselaraskan dengan proses teknis untuk memberikan karakter dan keindahan dalam hasil visualnya. Seni fotografi bukan sebuah rekaman yang apa adanya dari dunia nyata, tetapi menjadi karya seni yang kompleks dan media gambar yang memberi makna dan pesan. Ajidarma (2001:26) dalam teori yang digali dari Paul Messaris, gambargambar yang dihasilkan manusia, termasuk fotografi, bisa dipandang sebagai suatu keberakasaan visual. Dengan kata lain, gambargambar itu bisa dibaca, sehingga, konsekuensi pendapat gambar-gambar ini pun merupakan bagian dari suatu cara berbahasa. Jika berbahasa bisa diandaikan sebagai produk pikiran, dan pada gilirannya menjadi produk kebudayaan, dan tercipta wahana pengetahuan, maka demikian pula dengan penghadiran gambar-gambar.

Dalam penciptaan karya fotografi ini, seniman bereksperimen menghadirkan karya foto dengan menggunakan perangkat keras scanner yang dibumbui dengan sentuhan estetis telah berhasil menghadirkan sebuah domain baru dalam fotografi. Salah satu teknik dalam fotografi tersebut adalah scanography. Scanography merupakan singkatan dari scanner-photography atau scannerart, tidak lain dalam proses penciptaannya scanner digunakan sebagai alat perekamnya. Scanner dianggap tepat untuk merekam dan menjadikan objek tersebut dapat mewakili konsep foto yang diinginkan.

Menurut Sugiarto, penciptaan foto tanpa kamera (digital) ini dapat saja dikategorikan sebagai pekerjaan seni yaitu seni digital, karena cara membuatnya memang tak berbeda jauh dengan foto tanpa kamera (analog) yang biasa disebut fotogram, yang merupakan salah satu seni dalam fotografi... dengan perkembangan yang terus disempurnakan, membuat foto tanpa kamera secara digital yang mensyarati seperangkat komputer/laptop dan scanner pun, menjadi suatu hal yang mengasyikkan (2014:viii). Dalam hal ini seniman dapat mengeksplorasi objek ataupun efekefek yang dihasilkan dari scanner tersebut untuk penciptaan karya seninya. Scanography dapat mewakili fotografi dengan cara yang berbeda, yaitu objeknya terbatas akan tetapi narasinya sama dengan gagasan fotografi sebelumnya.

Karya-karya scanography berbentuk visual dwimatra tidak luput dari kemungkinan hadirnya berbagai tanda-tanda yang menyiratkan berbagai makna yang terkandung di dalamnya. Karya fotografi merupakan hasil rekaman yang menghadirkan suatu bentuk representasi sebuah objek yang kemudian menjadi subject matter karyanya. Subject matter dalam penciptaan karya tugas akhir fotografi ini merupakan sebuah representasi tentang perasaan yang terjadi dikehidupan sehari-hari. Bunga dipilih sebagai objek bahasa visual yang dianalogikan sebagai seorang perempuan yang diciptakan oleh Tuhan salah satunya dengan keindahan dan kecantikannya. Dalam hal ini, melalui bunga seseorang dapat berkomunikasi sebagai pengungkapan perasaan atau emosi melalui pesanpesan nonverbal sebagai pernyataan hubungan manusia yang satu dengan yang lainnya.

Gagasan-gagasan tersebut menjadi inspirasi dan mendorong timbulnya ide sebagai latar belakang terciptanya sebuah karya seni. Hal ini karena pada dasarnya proses penciptaan karya seni merupakan transferan perasaan di kehidupan nyata ke dalam media seni. Scanography dipilih sebagai media ekspresi untuk mengungkapkan bahasa ungkapnya dan menciptakan kedekatan antara perasaan dengan objek yang akan dibangunnya. Disisi lain, scanography diperkenalkan sebagai alternatif baru dalam fotografi yang diciptakan tanpa menggunakan kamera. Pengalaman pribadi diangkat sebagai subject matter yang diwakilkan oleh bunga sebagai objek penciptaan karya untuk menyampaikan sebuah perasaan ketika seseorang tidak mampu mengungkapkan dengan kata-kata.

Pemilihan representasi perasaan sebagai tema pada proses perwujudan karya seni ini, merupakan hasil perenungan dan pengamatan baik terhadap diri sendiri maupun diri terhadap lingkungan. Ada beberapa permasalahan yang menjadi dasar pemikiran dalam proses penciptaan karya seni ini. Pertama; Bunga sebagai simbol representasi perasaan dalam fotografi ekspresi. Kedua; Mewujudkan konsep visual bunga menggunakan teknik scanography. Upaya permasalahan ini dilakukan untuk memberi wacana baru kepada pelaku dan penikmat seni khususnya fotografi seni, tentang alternatif dalam fotografi yakni scanography.

\section{KAJIAN PUSTAKA}

\section{Scanography}

Dunia fotografi memberikan kesempatan bagi para fotografer untuk lebih serius dalam menanganinya dengan kata lain bahwa boleh dipikirkan adanya alternatif pengembangannya dalam berbagai aspek. Hal ini dimungkinkan bahwa fungsi fotografi sejauh ini sudah lebih dari sekadar menjadi alat atau media perekaman dokumentasi saja. Tetapi sudah menapak sebagai media untuk berekspresi dalam domain kesenian terutama yang bernuansa seni visual (Soedjono, 2007:50).

Foto tanpa kamera, mungkin sesuatu yang mustahil. Apalagi lazimnya kegiatan potret 
memotret menghasilkan sebuah foto selalu dilakukan dengan menggunakan kamera. Akan tetapi, meninjau prinsip dasar fotografi, photos dan graphos yang memiliki arti melukis dengan cahaya, maka foto tanpa kamera bukan lagi sesuatu yang mustahil. Sebelum membicarakan seni digital membuat foto tanpa kamera melalui sistem digital, perlu diketahui bahwasannya zaman dahulu fotogram merupakan salah satu alternatif karya seni fotografi yang dibuat tanpa menggunakan kamera namun tetap dengan menggunakan prinsip kerja cahaya.

Fotografi digital pun dalam penciptaannya tetap menggunakan prinsip cahaya, artinya fotografi digital tetap mempunyai dasar kerja yang tidak berubah dan menyimpang. Proses fotografi digital ini seseorang menciptakan foto dengan menggunakan sebuah alat pemindai atau scanner. Teknik tersebut disebut juga dengan scanography. Mengutip pernyataan dari sebuah situs website yaitu wikipedia

https://en.wikipedia.org/wiki/Scanography

diakses pada tanggal 30 Juli 2016, pada pukul 23.30) scanography atau disebut juga sebagai scanner art atau scanner photography adalah proses menangkap gambar digital sebuah objek yang ditujukan untuk menciptakan karya seni menggunakan scanner flatbed "foto" dengan CCD (Charge-Coupled Device).

Meskipun scanner memiliki kemampuan yang terbatas dalam menangkap kedalaman objek yang akan direkam, teknik ini dapat menghasilkan karya yang tidak kalah dengan fotografi. Secara fisik, scanner dilengkapi dengan sebuah lampu untuk menerangi atau memberi penyinaran pada objek, bekerjanya mirip mesin fotokopi, hanya saja scanner tidak dapat bekerja dengan baik bila tidak dihubungkan dengan perangkat komputer dan monitor atau laptop. Jika scanner telah tersambung dengan komputer/laptop, pemindaian objek dapat dilakukan dengan menekan tombol scan yang terlihat di monitor. Beberapa menit kemudian terjadilah alih imaji dari sebuah objek (umumnya lembaran) ke dalam sebuah komputer/laptop yang tersimpan dalam suatu folder. Maka dari itu, dengan digital penciptaan foto tanpa menggunakan kamera bukan lagi suatu teknik yang rumit, melainkan teknik yang mengasyikkan. Terlebih segala eksplorasi mengenai gambar yang diinginkan dapat dengan mudah berganti sesuai keinginan sebagai sebuah media ekpresi dalam penyampaian pesan.

\section{Perasaan}

Perasaan termasuk gejala jiwa yang dimiliki oleh semua orang, hanya corak dan tingkatannya tidak sama. Perasaan tidak termasuk gejala mengenal, walaupun demikian sering juga perasaan berhubungan dengan gejala mengenal. Perasaan ialah suatu keadaan kerohanian atau peristiwa kejiwaan yang kita alami dengan senang atau tidak senang dalam hubungan dengan peristiwa mengenal dan bersifat subjektif. Perasaan sejatinya mewakili sekian banyak rasa yang hadir dalam diri manusia untuk kemudian terekspresikan dalam perbuatan (Ahmadi, 1992:52).

Dari pernyataan tersebut dapat disimpulkan bahwa perasaan seseorang dapat berkembang sejak seseorang tersebut mengalami sesuatu. Sesuatu hal itu berwujud pada kenyataan yang dialaminya dan akan berubah menjadi sebuah pengalaman. Kemudian, pengalaman-pengalaman itu masuk ke dalam peristiwa-peristiwa kejiwaan berupa ingatan. Seseorang dapat mengingat sesuatu kejadian, berarti kejadian yang diingat itu pernah dialami atau sebatas dirasakan dan dimasukkan ingatan, kemudian disimpan dan ditimbulkan kembali atas kesadaran. Sehingga ingatan mampu menumbuh kembangkan perasaan seseorang menjadi senang atau tidak senang.

\section{Semiotika}

Saussure (1857-1913) dalam Danesi (2012:5) menyatakan semiotika adalah ilmu yang mempelajari tanda-tanda dalam masyarakat dapat dibayangkan ada. Ia akan menjadi bagian dari psikologi sosial dan karenanya juga bagian dari psikologi umum. Saya akan menyebutnya semiologi (dari bahasa Yunani, semeion "tanda"). Semiologi akan menunjukkan hal-hal yang membangun tandatanda dan hukum-hukum yang mengaturnya.

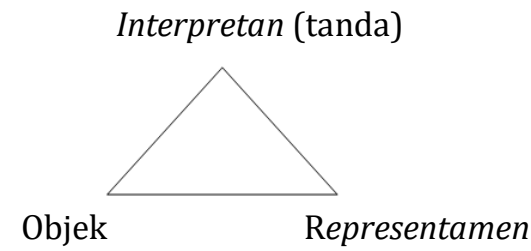

Gambar 1. Semiotika Charles Sander Peirce

Dipandang dari sisi hubungan representamen dengan objek, yakni dengan hubungan menggantikan atau the "standing for" relation, tanda-tanda diklasifikasikan oleh Pierce menjadi tiga tipe, yaitu:

a. Ikon

Ikon adalah tanda yang mengandung kemiripan "rupa" (resemblance) sebagaimana dapat dikenali oleh para pemakainya. Di dalam ikon hubungan representamen dan objeknya terwujud dalam "kesamaan dalam beberapa kualitas" (Budiman, 2011:20). Ikon menurut Danesi (2012:33) adalah tanda yang mewakili sumber acuan melalui sebuah bentuk replika, simulasi, imitasi, atau persamaan.

b. Indeks 
Indeks adalah tanda yang memiliki keterikatan fenomenal atau eksistensial di antara representamen dan objeknya. Didalam indeks hubungan antara tanda dan objeknya bersifat konkret, aktual dan biasanya melalui suatu cara sekuensial atau kausal (Budiman, 2011:20). Indeks menurut Danesi (2012:33) adalah tanda yang mewakili sumber acuan dengan cara menunjukkan padanya atau mengaitkannya (secara eksplisit atau implisit) dengan sumber acuan lain.

c. Simbol

(Budiman, 2011:22) simbol merupakan jenis tanda yang bersifat arbirter dan konvensional. Tanda-tanda kebahasaan pada umumnya adalah simbol-simbol. Dengan kata lain, tanda memiliki aspek mental dari tanda-tanda yang biasa disebut juga sebagai "konsep", yakni konsep-konsep ideasional yang bercokol di dalam benak penutur. Namun, simbol menurut Danesi (2012:33) adalah tanda yang mewakili objeknya melalui kesepakatan atau persetujuan dalam konteks spesifikasi.

Dalam penciptaan karya tugas akhir ini, ikon mengacu pada bunga untuk mewakili seorang perempuan. Indeks terwujud dalam segala macam perilaku representasif yang ada pada karya berupa hubungan anatar teks dengan tanda-tanda yang membentuk sebuah interpretasi. Simbol yang akan terwujud nantinya berupa objek-objek yang menjadi pendukung untuk merepresentasikan perasaan.

\section{TINJAUAN KARYA}

\section{Angki Purbandono}

Angki Purbandono lahir di Semarang, tepatnya di Desa Cepiring pada 24 September 1971. Seniman yang dikenal dengan intensitas eksplorasinya dengan medium fotografi ini pernah bersekolah di MSD (Modern 28 School of Design) Yogyakarta (1993-1994) sebelum kemudian melanjutkan studinya di Jurusan Fotografi Fakultas Seni Media Rekam (FSMR), Institut Seni Indonesia Yogyakarta (1994-1999).

Penjelajahan fotografis Angki Purbandono membawanya menembus batasan-batasan formal medium tersebut dan sering kali menghadirkan karya-karyanya dalam bentuk instalasi, video, sampai dengan scanography. Alih-alih membidik gambar melalui kamera, dia memilih menciptakan visual baru dari rangkaian benda temuannya yang direkamnya menggunakan mesin pemindai (scanner). Banyak dari karyanya menghadirkan karya scanography, mengeksplorasi benda-benda yang ia temui yang sesuai dengan tema yang diangkat sebagai penciptaan karya seni. Visualvisual yang dihadirkan sangat fantastik, dan menarik karena seseorang yang melihat akan menemui banyak tanda.
Berikut karya-karya Angki Purbandono yang dijadikan sebagai karya acuan.

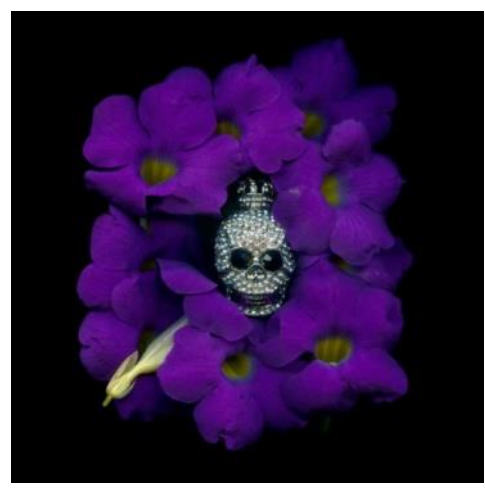

Gambar 2. King of Purple (2012) Sumber :

(http://weekendnotes.com/im/002/06/angkipurbandono-king-of-purple1.jpg, diakses pada tanggal 16 Maret 2016, pada pukul 08.15 WIB)

Foto pada gambar 2, "King of Purple" merupakan karya instalasi fotografi dalam pameran ART JOG 2012 yang diselenggarakan pada tanggal 14-28 Juli 2012 di Taman Budaya Yogyakarta dengan tema "Looking East - A Gaze upon Indonesian Contemporary Art". Proses penciptaan karya-karya fotografinya menggunakan teknik scanography.

Jika dilihat foto ini dominan berlatar belakang hitam, dengan menggambarkan sebuah tengkorak yang menggunakan mahkota berwarna silver berada di antara tumpukan bunga berwarna ungu. Foto tersebut dicetak menggunakan media scanography UV (print on acrylic light box installation), dengan format persegi berukuran 100 $\mathrm{x} 100 \mathrm{~cm}$.

Karya foto Angki Purbandono yang berjudul King of Purple cukup menarik. Karya foto ini tersusun dari ikon atau simbol yang mudah diidentifikasi, seperti bunga berwarna ungu. Sebagai sebuah ikon yang kehadirannya paling menonjol, bunga tersebut bukanlah semata sebuah ikon. Pada tahap semiosis, tanda ini mengacu kepada sebuah perasaan/pesan yang akan disampaikan oleh sang seniman. Ikon lainnya yaitu tengkorak, benda yang mirip dengan kepala manusia yang dapat diartikan sebagai raja. Tengkorak tersebut terselip diantara bunga-bunga. Tengkorak tersebut sebagai sebuah tanda ikonis. Makna judul King of Puple sebagai simbol yang memiliki arti sebagai raja ungu untuk memperkuat pernyataan bahwa karya tersebut adalah sebagai makna tahta sebuah kehidupan.

Karya-karya dalam penciptaan ini mengambil teknik scanography yang telah dipraktekkan lebih dulu oleh Angki Purbandono, dan permainan tanda-tanda digunakan sebagai bahasa ungkapnya. Perbandingan karya yang akan 
penulis ciptakan adalah dari segi bunga yang akan dipilih sesuai dengan perasaan yang ingin diungkapkan dan tanda-tanda lain sebagai pendukung yang mewakili situasi yang dialaminya.

\section{Toby Braun}

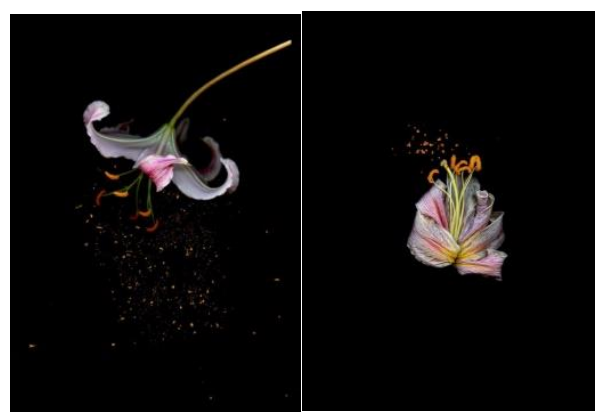

Gambar 3. Floriography

Sumber: http://utobia.tumblr.com/ (diakses pada tanggal 16 Maret 2016, pada pukul 10.30 WIB)

Karya gambar 3 merupakan hasil karya scanography yang dibuat oleh Toby Braun yang ditemukan penulis diinternet dengan menggunakan hastag \#floriography. Karya-karya tersebut merupakan proyek perekaman dengan menggunakan scanner dengan menggunakan objek bunga. Terlihat bunga-bunga tersebut dieksplorasi oleh Toby dengan baik, sehingga bunga tersebut diperlihatkan keindahannya. Dari beberapa yang dia ciptakan, Toby menjadikan bunga-bunganya sebagai arsip pribadi, untuk menghasilkan visual tentang bunga yang cantik.

Karya-karya Toby Braun dijadikan sebagai referensi atas kemiripan visual yang akan tercipta dalam tugas akhir ini. Yang membedakan dari karya-karya Toby dengan karya-karya tugas akhir yang akan diciptakan terletak pada objek yang bukan dijadikan sebagai sebuah arsip, melainkan sebagai pengungkapan suasana hati yang pernah dialami dan dijalani oleh seniman itu sendiri.

\section{METODE PENCIPTAAN}

\section{Kontemplasi-Idealisasi}

Dalam Kamus Besar Bahasa Indonesia (2007:591) kontemplasi artinya renungan, dengan kebulatan pikiran atau perhatian penuh. Proses ini dilakukan setelah data-data penciptaan berhasil dihimpun. Kontemplasi dilakukan ketika mendapatkan rangsangan atas gejala-gejala yang terjadi pada pencipta karya. Gejala-gejala yang dialami berupa pengalaman pribadi sehingga perasaan itu muncul. Setelah tahap kontemplasi kemudian berlanjut pada tahap idealisasi, yakni berbentuk pada sebuah rancangan, rencana dan cita-cita mengenai tema-tema dan bentuk-bentuk perwujudan karya yang paling tepat.

\section{Perencanaan}

Melakukan perencanaan eksekusi. Tahap ini sekaligus memilih bunga dan benda yang digunakan sebagai simbol dan teknik fotografi apa yang kirakira merepresentasikan ide tentang perasaan yang sedang dibangun. Perencanaan adalah salah satu proses penting menuju kesiapan saat eksekusi, juga sebagai fondasi nantinya saat proses eksekusi. Fondasi yang dibangun bersifat tidak membatasi, maksudnya ide dibangun dari satu peristiwa. Saat proses pemotretan tidak menutup kemungkinan ide akan berkembang dengan sendirinya.

\section{Eksplorasi, Eksperimentasi, dan Eksekusi}

Setelah dirasa semua kebutuhan pemotretan sudah siap, maka tahap selanjutnya adalah eksekusi. Pada tahap ini, proses eksplorasi dan eksperimentasi bersamaan dengan waktu eksekusi. Eksplorasi dan eksperimentasi yang dilakukan menyangkut komposisi dan teknik yang sesuai dengan ide serta interaksinya.

\section{Editing}

Tahap eksekusi tentu tidak menghasilkan satu foto saja, tetapi ada beberapa foto yang berpotensi untuk dipilih. Di tahap inilah proses pemilihan foto terbaik dilakukan. Foto yang akhirnya dipilih berdasarkan dengan ide yang akan disampaikan. Setelah itu baru dilakukan finishing hasil dari tahap pemindaian menggunakan photoshop.

Saat eksekusi terkadang ada beberapa objek yang apabila digabungkan tidak masuk dalam frame scanner. Maka dalam tahapan ini dilakukan perekaman dua kali kemudian disatukan menggunakan photoshop.

\section{PEMBAHASAN}

Dalam pembahasan karya ini, pencipta akan menguraikan beberapa karya scanography yang telah diciptakan. Hal ini dapat dijadikan sebagai cara untuk mengetahui sejauh mana pencipta membuat karya fotografi sesuai dengan tema dan visual yang diinginkan. Dalam proses penciptaannya, karya awal - karya akhir diciptakan dengan menggunakan mesin scanner tanpa menggunakan proses digital imaging. Cara kerja yang dihasilkan menggunakan scanner juga berpengaruh pada visual yang akan ditampilkan, misalnya penggunaan background hitam dihasilkan dengan cara membuka penutup scanner, apabila ingin menghasilkan background berwarna putih pencipta dapat menutup penutup scanner atau dapat menggunakan kertas karton putih, plastik putih, dll. Pencipta memiliki banyak sekali gagasan/ide yang ingin diungkapkan, namun 
karena keterbatasan waktu maka tidak semua gagasan dapat direalisasikan ke dalam wujud karya foto.

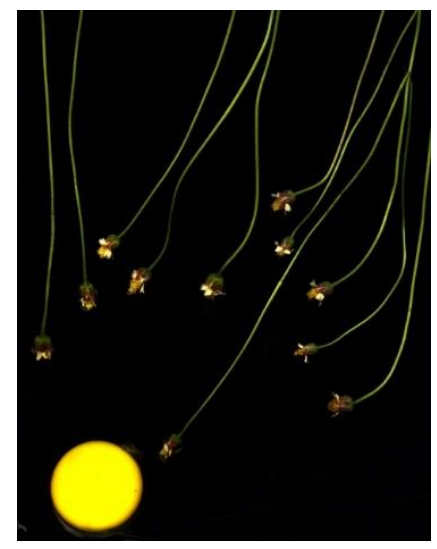

Gambar 4. Karya foto 1. Judul : Bungah. 2016.

( Galuh Paramithasari, 60 x $90 \mathrm{~cm}$. Cetak digital pada kertas. )

Dalam karya foto ini visual yang dihadirkan sebanyak dua buah objek, di antaranya bunga dan sebuah benda berbentuk bulat berwarna kuning. Objek berbentuk bulat berwarna kuning yang tergambar pada karya foto 1 adalah sebuah telur yang dipecahkan di atas scanner. Proses pembuatan karya ini dilakukan dengan cara memberi alas plastik $p v c$ (plastik sampul buku) yang diletakkan diatas scanner hal ini digunakan untuk melindungi scanner dan untuk meminimalisir adanya cairan yang meresap kedalam scanner kemudian telur dapat dipecahkan diatas scanner. Sedangkan jenis bunganya adalah bunga-bunga yang tumbuh liar di pinggir-pinggir jalan atau di lapangan. Karya ini memvisualisasikan terjadinya pembuahan di dalam rahim seorang perempuan. Warna hitam pada background dihadirkan untuk memberikan kesan dramatis.

Karya ini berjudul bungah, dalam bahasa Jawa bungah mempunyai arti senang, gembira, bahagia judul ini dipilih sebagai representasi kebahagiaan seorang perempuan yang memiliki naluri keibuaan atas janin yang dikandungnya. Dalam karya tersebut bunga dipilih sebagai interpretasi sperma, sedangkan bentuk bulat berwarna kuning diinterpretasikan sebagai tuba falopi di mana tempat sel telur berada.

Dalam visual karya tersebut bunga yang diibaratkan sebagai sperma-sperma melakukan perjalanan dari leher rahim ke tuba falopi tempat sel telur berada. Terlihat ada salah satu bunga dari beberapa bunga yang tergambarkan pada karya ini adalah sperma pertama, sperma pertama yang bertemu dengan sel telur akan berusaha menembus cangkang sel agar terjadi pembuahan dan saat itulah janin akan terbentuk.
Latar belakang timbulnya karya ini berawal dari diri seniman yang memiliki kodrat sebagai perempuan dan memiliki naluri keibuan. Kehadiran buah hati inilah yang membuat sebuah hidup bersama pasangan akan bahagia. Meskipun hal tersebut belum dirasakan, sejatinya seorang perempuan akan bahagia hanya dengan melihat dan mendengarkan kabar dari orang terdekatnya.

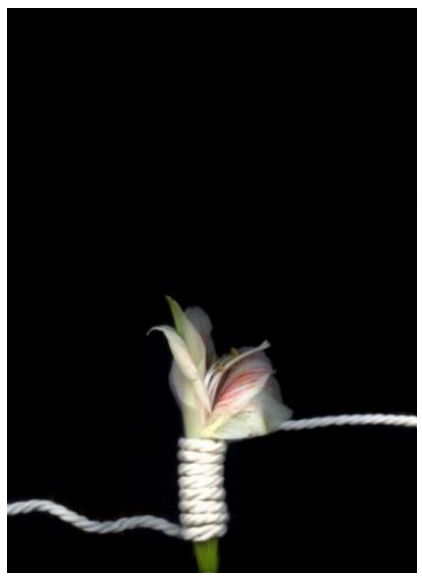

Gambar 5. Karya Foto 2. Judul : Terjerat. 2016. (Galuh Paramithasari, 60 x $90 \mathrm{~cm}$. Cetak digital pada kertas. )

Karya berjudul "Terjerat" menghadirkan visualisasi sangat kuat. Terdapat dua buah objek, yakni sebuah bunga yang dililit oleh tali. Latar belakang yang berwarna hitam dihasilkan dengan membuka penutup scanner, background hitam dihadirkan untuk menambah kesan point of interest pada objek tersebut.

Karya ini menceritakan tentang pengalaman pribadi pada saat mendapat perlakuan posesif. Posesif berarti sikap yang ditunjukkan untuk mengontrol seseorang, atau bisa juga diartikan sebagai sebuah sikap membatasi ruang gerak. Sikap seperti ini dirasakan penulis saat menginjak usia remaja. Sikap-sikap yang diperlakukan untuk mengontrol seseorang inilah yang membuat keadaan terjerat sering kali membuat penulis kurang bebas bergerak, dan merasa tertekan.

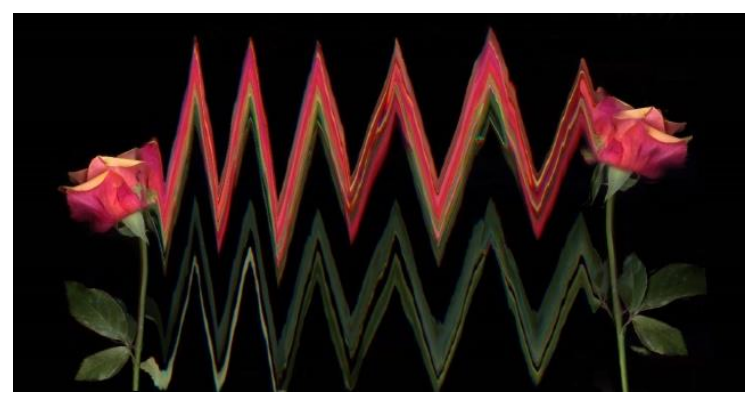

Gambar 6. Karya Foto 3. Judul : Resah. 2016. (Galuh Paramithasari, $60 \times 90 \mathrm{~cm}$. Cetak digital pada kertas. ) 
Dalam karya diatas tergambar dua objek bunga mawar berwarna merah semi orange yang saling membelakangi. Di antara dua bunga mawar tersebut dihubungkan oleh sebuah garis berbentuk zigzag. Garis zigzag merupakan garis patah-patah bersudut runcing, dibuat dari gabungan vertikal dan diagonal sebagai asosiasi petir, retak, letusan. Menggambarkan karakter gairah, semangat, bahaya, mengerikan, nervous. Garis zigzag dihadirkan untuk mewakili perasaan gelisah yang menandakan bahaya di antara kedua bunga tersebut. Garis zigzag ini dibuat dengan memanfaatkan teknik slow motion pada scanner seperti yang digunakan pada teknik fotografi dengan cara menggerakkan objek mengikuti lampu yang bergerak pada saat scanning membentuk sebuah garis zig-zag. Latar belakang hitam dihadirkan untuk mewakili ruang hati yang gelap.

Karya ini bercerita tentang sebuah kegelisahan. Pada dasarnya manusia tidak pernah lepas dari rasa cemas dan kegelisahan, karena hal tersebut merupakan bagian dari dirinya. Rasa cemas ini bersifat alami, hal itu terjadi dibawah kekuasaan manusia itu sendiri. Dalam karya ini, bunga mawar dihadirkan sebagai representasi dua orang laki-laki dan perempuan yang saling membelakangi dengan dibayangi rasa kegelisahan. Rasa kegelisahan hadir karena adanya keterbatasan jarak yang menjadikannya cemas akan orang yang disayangi dalam menantikan sebuah kabar. Garis zigzag dipilih untuk melambangkan perasaan kegelisahan tersebut.

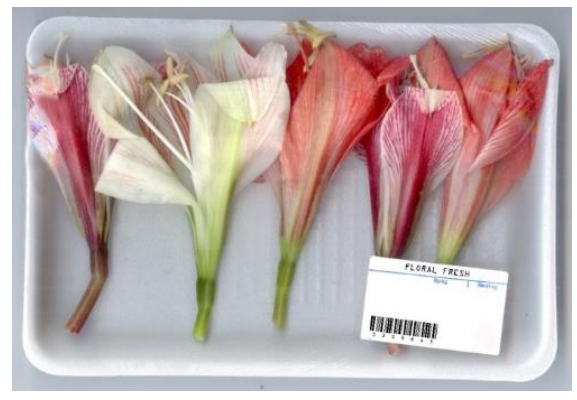

Gambar 7. Karya Foto 4. Judul : Beauty is Pain. 2016.

( Galuh Paramithasari, $60 \times 90 \mathrm{~cm}$. Cetak digital pada kertas. )

Karya ini menghadirkan visual lima bunga yang dikemas rapi dan di-pappingwrap. Pengemasan papingwrap digunakan sebagai simbol melindungi diri dari luar, namun di sisi lain pengemasan tersebut memberi kesan penekanan/pemaksaan pada objek. Simbol bardcode yang dihadirkan untuk memberikan kesan mahal dengan adanya perawatan/pengemasan. Kelima objek bunga tersebut adalah bunga amarilis, bunga amarilis memiliki arti kebanggan, ketakutan, megah, dan indah. Pemilihan bunga amarilis memaknai kebanggaan atas dirinya yang memiliki keindahan/kecantikan.

Judul yang diberikan adalah "Beauty is Pain", kata tersebut memiliki arti cantik itu sakit. Bagi kalangan perempuan yang melakukan perawatan diri di sebuah klinik kecantikan kata tersebut tidaklah asing. Karya ini menceritakan rutinitas seorang perempuan yang kerap melakukan perawatan di klinik kecantikan. Zaman sekarang untuk menjadi cantik dan sempurna memang membutuhkan pengorbanan dan biaya yang mahal. Penulis sendiri menyadari akan hal itu, dan dialami oleh penulis. Tuntutan zaman membuat perempuan berlomba-lomba untuk menjadikan dirinya sempurna hingga mengeluarkan jutaan rupiah untuk sebuah pujian cantik. Semua itu tidak bisa dipungkiri, para perempuan pun juga rela bahwa dirinya harus menyakiti diri sendiri oleh perawatan tersebut agar dirinya bisa terlihat memukau.

\section{KESIMPULAN}

Penciptaan karya seni "Representasi Bunga dalam Fotografi Ekspresi" menghadirkan tantangan yang sangat menarik karena scanography merupakan perkembangan teknik baru dari ide lama. Dengan menggunakan media digital berupa mesin scanner, penulis mendapatkan pengalaman dan pemahaman dalam proses berkarya yang baru. Penulis mendapat pengembangan baik dari segi visual maupun secara teknik dengan pemanfaatan media scanner untuk mewujudkan karya seni fotografi yang berbeda.

Dinamika perasaan yang ada dalam pribadi penulis menjadi sebuah sarana pengekspresian ideide. Representasi perasaan sebagai ajang 'curhat' tentang kondisi yang pernah dialami seperti perasaan memaknai kehidupan, perasaan terluka, tertekan, kasih sayang, dan bahagia diungkapkan dengan menggunakan bahasa bunga. Setiap karya scanography yang diciptakan oleh penulis menghadirkan sebuah visual yang bertujuan memberi sebuah pesan tentang yang ingin disampaikan dalam masing-masing karya. Walau interpretasi orang berbeda-beda, itu menambah nilai tambah bagi karya yang dibuat penulis sehingga perbedaan persepsi dalam menilai karya memiliki keindahan yang tidak ternilai harganya.

\section{DAFTAR PUSTAKA}

Ajidarma, Seno Gumira. 2001. Kisah Mata. Yogyakarta: Galang Press.

Ahmadi, Abu. dan M. Umar M.A. 1992. Psikologi Umum. Surabaya: PT. Bina Ilmu.

Budiman, Kris. 2011. Semiotika Visual 'Konsep, Isu dan Problem Ikonitas'. Yogyakarta: Jalasutra. 
Danesi, Marcel. 2012. Pesan, Tanda, dan Makna, 'Buku Teks Dasar Mengenai Semiotika dan Teori Komunikasi'. Yogyakarta: Jalasutra.

Herusatoto, Budiono. 1991. Simbolisme dalam Budaya Jawa. Yogyakarta: Hanindita.

Marjanin, Muchlis dan Hadmadi M. 1982. Ilmu Hayat Dalam Pertanian (Jilid I Botani). Jakarta: Yasaguna.

Pusat Bahasa, Departemen Nasional. 2007. Kamus Besar Bahasa Indonesia Edisi Ketiga. Jakarta: Balai Pustaka.

Sugiarto, Atok. 2014. Seni Digital Kiat-Kiat Membuat Foto Tanpa Kamera. Jakarta: PT Elex Media Komputindo.

Susanto, Mike. 2011. Diksi Rupa: Kumpulan Istilah \& Gerakan Seni Rupa Edisi Revisi. Yogyakarta: DictiArt Lab, Bali: Jagad Art Space.

Soedjono, Soeprapto. 2006. Pot-Pourri Fotografi. Jakarta: Penerbit Universitas Trisakti.

Walgito, Bimo. 1990. Pengantar Psikologi Umum. Yogyakarta: ANDI.
Nugroho, Gunawan Edy. 2003. "Eksplorasi Fotogram Sebagai Karya Fotografi". Skripsi. Program Studi S-1 Fotografi Institut Seni Indonesia. Yogyakarta.

Sulistiyani, Nanik. 2013. "Kajian Semiotika KaryaKarya Angki Purbandono". Skripsi. Program Studi Pendidikan Seni Rupa Universitas Negeri Yogyakarta. Yogyakarta.

Yunanto, Deddy. 2004. "Bunga Sebagai Inspirasi Karya Seni Grafis”. Skripsi. Program Studi S-1 Seni Grafis Institut Seni Indonesia Yogyakarta.

https://en.wikipedia.org/wiki/Scanography/, diakses pada tanggal 15 Maret 2016, pada pukul 22.20 WIB

http://weekendnotes.com/im/002/06/angkipurbandono-king-of-purple1.jpg, (diakses pada tanggal 16 Maret 2016, pada pukul 08.15 WIB).

https://utobia.tumblr.com/post/96905599685/un titled-wilted-lily-floral-decay-scan-by-toby (diakses pada tanggal 16 Maret 2016, pada pukul 10.30 WIB). 